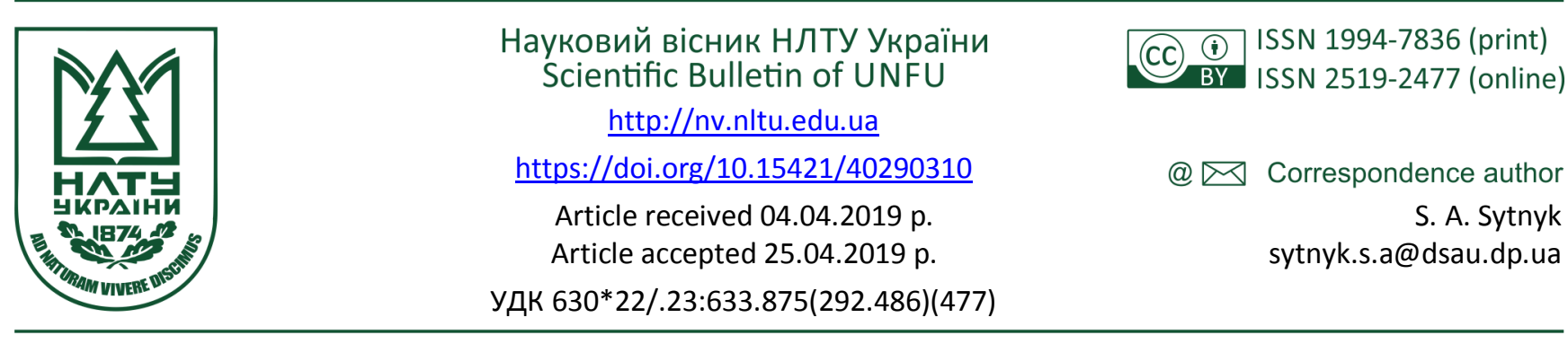

С. А. Ситник

Дніпровський державний аграрно-економічний університет, м. Дніпро, Украӥна

\title{
МОДЕЛЮВАННЯ КОМПОНЕНТІВ ФІТОМАСИ СТОВБУРІВ РОБІНІЄВИХ ДЕРЕВОСТАНІВ ПІВНІЧНОГО СТЕПУ УКРАЇНИ
}

Наведено результати математичного моделювання компонентів фітомаси стовбурів робінієвих деревостанів у степовій зоні України за компонентами фітомаси стовбурів та їх залежність від основних таксаційних характеристик деревостану. Дослідження проведено на 20 тимчасових пробних площах у робінієвих деревостанах Дніпропетровської області, підпорядкованих Державному агентству лісових ресурсів України. Сформовано робочий масив даних, який характеризує компоненти фітомаси стовбура для оцінювання біотичної продуктивності штучних робінієвих деревостанів. Для виявлення характеру розподілу досліджуваних параметрів та забезпечення адекватності математичних моделей проведено статистичний аналіз дослідних даних та кореляційний аналіз. В отриманих математичних моделях спостерігається обернений зв'язок серед досліджуваних компонентів фітомаси стовбура із середнім діаметром насадження. Відносна повнота насадження $є$ статистично значущою при введені ії в рівняння поряд з середнім діаметром та середньою висотою деревостанів. Розраховано конверсійний коефіцієнт (відношення фітомаси стовбура у корі до загального запасу стовбурів у корі), значення якого знаходяться в діапазоні 0,37-1,12. Наведено фрагменти нормативних таблиць оцінювання компонентів фітомаси стовбурів штучних деревостанів робінії несправжньоакації з відносною повнотою 0,9 .

Ключові слова: степ; насадження; регресійні рівняння; Robinia pseudoacacia L.; нормативні таблиці.

Вступ. Інтерпретація результатів інтродукції і культивування робінії несправжньоакації (Robinia pseudoacacia L.) у лісових насадженнях поза межами природнього ареалу неоднозначна. Різноспрямовані погляди вчених на поширення і функціонування цього виду викладено у дослідженнях останніх років. Lazzaro L. зі співавторами вказують на трансформацію компонентів природних екосистем, модифікацію грунтів і фітоценозів при культивуванні робінієвих насаджень (Lazzaro et al., 2018). На наш погляд, для запобігання і уникнення порушень екологічної рівноваги потрібно виважене i доцільне управління робінієвими насадженнями, тому що достатньою кількістю наукових робіт підтверджено значний ремедіаційний потенціал цього виду при рекультивації антропогенно трансформованих земель у Китаї, Німеччині, Україні (Carl et al., 2018; Liang et al., 2018; Liu et al., 2018).

Carl C. із співавторами досліджували ріст дерев робінії несправжньоакації у штучних насадженнях різного віку лісостанів Німеччини та залежність ростових процесів від вологозабезпеченості грунту і концентрації елементів мінерального живлення (азоту, фосфору). У poботі Liang H. проаналізовано вплив просторово-часових коливань вологості грунту на формування фітомаси рекультиваційних насаджень Robinia pseudoacacia на плато Лесу (Loess Plateau) у Китаї. Дослідженням Liu D. із співавторами доведено, що насадження робінії несправжньоакації, що функціонують для запобігання ерозійним процесам на рекультивованих землях, мають значний потенціал для трансформації фіто- та мікробіомаси у грунтах у напрямку поліпшення його фізико-хімічних властивостей та збільшення вмісту фосфору.

Одним із перших кроків для доцільного менеджменту насадженнями, зокрема і робінієвими, є розуміння закономірностей формування надземної фітомаси, тобто оцінювання їх біотичної продуктивності у нових едафо-кліматичних умовах розвитку цих насаджень.

Фітомаса деревостану, як компонент біотичної продуктивності, є його комплексною біометричною характеристикою, яку можливо оцінювати через використання методів математичного моделювання, які водночас мають базуватися на репрезентативних дослідних даних, отриманих у польових дослідженнях.

Встановлення регіональних особливостей формування фітомаси штучних робінієвих деревостанах Степу України та опрацювання системи нормативно-довідкових даних її оцінки є тією основою, яка дасть змогу вирішувати екологічні та ресурсно-економічні завдання регіону. 3 огляду на це виникла потреба у розробленні регіональних нормативів робінії несправжньоакації, деревостани якої у Північному Степу України (у межах Дніпропетровської обл.) поширені на площі 17683,7 га, переважно виконують функції протиерозійного захисту грунтів та формують рекультиваційні насадження на антропогенно трансформованих землях (Lakyda \& Sytnyk, 2014).

\section{Інформація про авторів:}

Ситник Світлана Анатоліївна, канд. біол. наук, доцент, кафедра садово-паркового господарства. Email: sytnyk.s.a@dsau.dp.ua; https://orcid.org/0000-0002-7646-6347

Цитування за ДСтУ: Ситник С. А. Моделювання компонентів фітомаси стовбурів робінієвих деревостанів Північного Степу України. Науковий вісник НлтУ України. 2019, т. 29, № 3. С. 48-51.

Citation APA: Sytnyk, S. A. (2019). Modeling of the trunk phytomass components of black locust stands in Northern Steppe of Ukraine. Scientific Bulletin of UNFU, 29(3), 48-51. https://doi.org/10.15421/40290310 
Мета дослідження - розроблення нормативно-інформаційного забезпечення компонентів фітомаси стовбурів штучних насаджень робінії несправжньоакації у регіоні дослідження.

Матеріали і методи дослідження. Для здійснення дослідження у робінієвих деревостанах Північного Степу України (у межах Дніпропетровської обл.) було закладено 20 тимчасових пробних площ за загальноприйнятою лісотаксаційною методикою за попередньо проаналізованими матеріалами лісовпорядкування (Lakyda, 2002).

Розрахунок математичних моделей взаємозв'язку основних компонентів фітомаси стовбурів робінієвих деревостанів із таксаційними показниками насаджень здійснювали з використанням прямої регресії. Методи прямої регресії відображають статистичну залежність досліджуваної змінної від аргументів, які характеризують досліджуваний об'єкт абсолютними величинами.

Враховуючи досвід моделювання у попередніх дослідженнях біотичної продуктивності компонентів фітомаси деревостанів науковців школи П. І. Лакиди (Lakyda, 2002; Lakyda \& Blyhhik, 2010; Lakyda et al., 2011), пошук математичних моделей взаємозв'язку компонентів фітомаси стовбурів штучних деревостанів робінії несправжньоакації у Північному Степу України здійснювали з використанням такої алометричної залежності:

$$
P h_{i}=f(D, H, P),
$$

де: $P h_{i}-$ відповідні компоненти фітомаси стовбурів деревостанів робінії несправжньоакації, т га ${ }^{-1} ; f(D, H, P)-$

Табл. 1. Основні статистики розподілу таксаційних показників і компонентів фітомаси стовбурів робінісвих деревостанів

\begin{tabular}{|c|c|c|c|c|c|c|}
\hline \multirow{2}{*}{ Ознака } & \multicolumn{2}{|c|}{ Значення } & \multicolumn{4}{|c|}{ Статистики } \\
\cline { 2 - 7 } & $\min$ & $\max$ & $\dot{X}$ & $\begin{array}{c}\text { Стандартне } \\
\text { відхилення }\end{array}$ & Асиметрія & \multirow{2}{*}{ Ексцес } \\
\hline$A$ (вік), років & 3,00 & 82,0 & 44,8 & 21,37 & $-0,175$ & 0,139 \\
\hline$D_{1,3}$ (діаметр стовбуру), см & 3,90 & 26,00 & 17,73 & 6,80 & $-0,704$ & $-0,096$ \\
\hline$H$ (висота), & 5,20 & 21,50 & 15,72 & 5,01 & $-1,065$ & 0,661 \\
\hline$P($ відносна повнота) & 0,10 & 1,45 & 0,724 & 0,35 & $-0,111$ & 0,421 \\
\hline$P h_{\partial}\left(\right.$ фітомаса деревини), $\mathrm{T}^{\cdot} \mathrm{ra}^{-1}$ & 0,61 & 119,73 & 63,77 & 33,63 & $-0,560$ & 0,043 \\
\hline$P h_{\kappa}\left(\right.$ фітомаса кори), $\cdot \mathrm{ra}^{-1}$ & 0,05 & 43,52 & 23,72 & 13,28 & $-0,458$ & $-0,583$ \\
\hline$P h_{\partial+\kappa}\left(\right.$ фітомаса стовбура в корі), $\mathrm{T}^{-1} \mathrm{ra}^{-1}$ & 0,66 & 136,38 & 87,49 & 43,95 & $-0,973$ & 0,029 \\
\hline
\end{tabular}

Під час здійснення регресійного аналізу необхідно враховувати кореляційні зв'язки між незалежними змінними. У табл. 2 наведено кореляційну матрицю компонентів фітомаси стовбурів і таксаційних ознак деревостанів.

Табл. 2. Коефіціснти кореляції компонентів фітомаси стовбурів з таксаційними ознаками робінісвих деревостанів

\begin{tabular}{|c|c|c|c|c|c|c|c|}
\hline Показник & $\begin{array}{c}A, \\
\text { років }\end{array}$ & $\begin{array}{c}D_{1,3}, \\
\text { cM }\end{array}$ & $H, \mathrm{~m}$ & $P$ & $\begin{array}{l}P h_{\partial} \\
\tau^{\prime} \cdot \Gamma a^{-1}\end{array}$ & $\begin{array}{l}P h_{k} \\
\text { т.га }\end{array}$ & 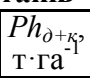 \\
\hline$A$, років & 1 & & & & & & \\
\hline$D_{1,3}, \mathrm{~cm}$ & 0,81 & 1 & & & & & \\
\hline$H, \mathrm{M}$ & 0,74 & 0,94 & 1 & & & & \\
\hline$P$ & 0,59 & 0,57 & 0,67 & 1 & & & \\
\hline$P h_{\partial}, \mathrm{T} \cdot \boldsymbol{\Gamma a}^{-1}$ & 0,65 & $-0,63$ & 0,78 & 0,90 & 1 & & \\
\hline$P h_{\kappa}, \mathrm{T} \cdot г \mathrm{a}^{-1}$ & $-0,05$ & $-0,17$ & 0,32 & 0,33 & 0,70 & 1 & \\
\hline$P h_{\partial+k}, \mathrm{~T} \cdot r \mathrm{a}^{-1}$ & 0,62 & $-0,61$ & 0,77 & 0,91 & 0,72 & 0,69 & 1 \\
\hline
\end{tabular}

Аналіз отриманих показників свідчить, що для фітомаси деревини стовбурів спостерігається наявність тісного прямого кореляційного зв'язку з відносною повнотою та середньою висотою деревостану. Значення коефіцієнтів кореляції вказують на значущий тісний обернений зв'язок усіх досліджуваних компонентів фітомаси стовбура із середнім діаметром деревостану.

Враховуючи результати розрахунків, відібрано регресійні моделі, які рекомендовано для побудови нормасередній діаметр, середня висота та відносна повнота.

У процесі багатоваріантного пошуку регресійних моделей значущість впливу чинників на досліджувані компоненти фітомаси стовбурів оцінювали на $5 \%$-му рівні за довірчими інтервалами коефіцієнтів регресії. Адекватність отриманих моделей оцінювали за коефіцієнтами детермінації розрахованих рівнянь.

Результати дослідження. Моделювання залежностей компонентів фітомаси стовбурів робінієвих деревостанів здійснювалося на основі робочого масиву даних, який характеризує компоненти надземної фітомаси деревостану: масу деревини стовбуру $-P h_{\partial}$; масу кори стовбурів - $P h_{\kappa}$; масу деревини стовбурів у корі $-P h_{\partial+\kappa}$, так і основні таксаційні ознаки деревостану - середній діаметр, середню висоту та відносну повноту - як аргументи регресійних рівнянь.

Для виявлення характеру розподілу досліджуваних параметрів та забезпечення адекватності математичних моделей проведено статистичний аналіз дослідних даних. Отримані значення основних статистик наведено в табл. 1. Для вибірки об'ємом 20 одиниць критичне значення показника асиметрії дорівнює $0,711(p \leq 0,05)$, ексцесу (E) - 0,907 ( $p \leq 0,01)$ (Yantsev, 2012). Сукупності даних, що характеризують деревостани - вік, середній діаметр стовбурів, відносна повнота, фітомаса деревини та кори стовбурів, мають характеристики нормального розподілу, тобто не перевищують критичне значення показників асиметрії та ексцесу. функції відповідних таксаційних ознак деревостану- тивних таблиць оцінювання фітомаси стовбурів робінієвих деревостанів досліджуваного регіону (табл. 3).

Табл. 3. Моделі для оцінювання компонентів надземної фітомаси деревостанів робінії несправжньоакації

\begin{tabular}{|c|c|c|}
\hline $\begin{array}{c}\text { Номер } \\
\text { моделі }\end{array}$ & Вид рівняння & $\begin{array}{c}\text { Коефіціснт } \\
\text { детермінації }\end{array}$ \\
\hline 1 & $P h_{\partial}=15,315 \cdot D^{-0,817} \cdot H^{1,451} \cdot P^{0,77}$ & 0,93 \\
\hline 2 & $P h_{\kappa}=0,074 \cdot D^{-0,180} \cdot H^{2,046} \cdot P^{-0,044}$ & 0,96 \\
\hline 3 & $P h_{\partial+\kappa}=7,143 \cdot D^{-0,612} \cdot H^{1,011} \cdot P^{0,526}$ & 0,96 \\
\hline
\end{tabular}

Аналізуючи отримані математичні моделі, можна стверджувати, що вони адекватно описують дослідні дані 3 високим рівнем апроксимації, про що свідчать достовірні значення коефіцієнтів детермінації $\left(Q^{2}=\right.$ 0,93-0,96).

В усіх наведених моделях спостерігається обернений зв'язок усіх досліджуваних компонентів фітомаси стовбура із середнім діаметром насадження, який варіює в межах від -0,180 до -0,817, що свідчить про таксаційну і біологічну коректність залежності. Класична формула таксації зазначає, що за рівних параметрів середньої висоти і повноти деревостану - збільшення середнього діаметра повинно знижувати середнє старе видове число, а отже, запас деревостану та відповідно фітомасу. У деревостанах з однаковою середньою висотою і відносною повнотою фітомаса деревини стовбу- 
рів, кори стовбурів та стовбурів у корі буде більшою у тому, де меншим $є$ середній діаметр.

Відносна повнота насадження $є$ статистично значущою при введенні їі в рівняння поряд із середнім діаметром та середньою висотою деревостанів, 3 додатним показником ступеня, що відповідає закономірностям інтегрування компонентів фітомаси стовбуру. На наступному етапі дослідження розраховано конверсійний коефіцієнт - показник відношення надземної фітомаси стовбурів у корі робінієвих деревостанів до запасу стовбурів у корі (табл. 4).

Табл. 4. Відношення фітомаси стовбурів робінієвих деревостанів до запасу у корі

\begin{tabular}{|c|c|c|c|c|c|c|c|c|c|c|}
\hline Діаметр & \multicolumn{10}{|c|}{ Висота, м } \\
\hline cM & 6 & 8 & 10 & 12 & 14 & 16 & 18 & 20 & 22 & 24 \\
\hline 4 & 1,12 & & & & & & & & & \\
\hline 6 & 1,03 & 0,93 & & & & & & & & \\
\hline 8 & 0,93 & 0,83 & 0,77 & & & & & & & \\
\hline 10 & 0,86 & 0,77 & 0,71 & 0,66 & & & & & & \\
\hline 12 & & 0,72 & 0,66 & 0,62 & & & & & & \\
\hline 14 & & & 0,63 & 0,59 & 0,56 & & & & & \\
\hline 16 & & & 0,61 & 0,57 & 0,53 & 0,51 & & & & \\
\hline 18 & & & & 0,55 & 0,52 & 0,49 & 0,47 & & & \\
\hline 20 & & & & & 0,50 & 0,48 & 0,46 & 0,56 & & \\
\hline 22 & & & & & & 0,46 & 0,45 & 0,43 & 0,42 & \\
\hline 24 & & & & & & & 0,44 & 0,42 & 0,41 & 0,40 \\
\hline 26 & & & & & & & & 0,41 & 0,40 & 0,39 \\
\hline 28 & & & & & & & & & 0,39 & 0,3 \\
\hline 30 & & & & & & & & & & 0,37 \\
\hline
\end{tabular}

Конверсійний коефіцієнт для модальних деревостанів робінії несправжньоакації Північного Степу України знаходиться в діапазоні значень 1,12-0,37. Найбільші значення розрахованого коефіцієнта характерні для деревостанів 3 найменшими значеннями діаметра стовбура і висоти. Зі збільшенням значень таксаційних характеристик деревостану - середньої висоти та середнього діаметра відбувається закономірне зниження конверсійного коефіцієнта, який досягає мінімуму в деревостанах 3 найбільшими значеннями середніх діаметрів і середніх висот.

Після побудови моделей для оцінювання компонентів фітомаси стовбурів робінієвих деревостанів та розрахунку конверсійних коефіцієнтів, важливим етапом $є$ екстраполяція знань про об'єкт дослідження.

Одним 3 найпоширеніших методів практичного узагальнення отриманих теоретичних математичних результатів є розроблення нормативних таблиць. Завдяки інформативності й адекватності досліджуваним процесам, таблиці нормативів набули широкого застосування для вирішення багатьох прикладних завдань як у лісотаксаційній практиці, так і в галузях лісівництва та екології. Для доцільності лісогосподарського використання нормативні таблиці компонентів фітомаси стовбура робінієвих деревостанів представлено залежно від середнього діаметра та середньої висоти деревостанів.

Отже, за результатами проведених розрахунків було одержано нормативні таблиці оцінювання фітомаси стовбурів досліджуваних насаджень для таких фракцій: 1) деревина стовбурів; 2) кора стовбурів; 3) стовбури у корі.

Фрагменти нормативних таблиць оцінювання компонентів фітомаси стовбурів штучних деревостанів робінії несправжньоакації з відносною повнотою 0,9 наведено в табл. 5-7. Розраховані нормативи можуть бути рекомендовані до використання у робінієвих деревостанах із середньою висотою в межах від 4 до 30 м та се- реднім діаметром - від 4 до 32 см включно в діапазоні модальних повнот $0,6-0,9$.

Табл. 5. Фітомаса деревини стовбурів у абсолютно сухому стані, $\mathbf{T} \cdot \mathbf{r a}^{-1}$

\begin{tabular}{|c|c|c|c|c|c|c|c|c|c|c|}
\hline Дiаметр & \multicolumn{10}{|c|}{ стані, т.га } \\
\cline { 2 - 11 } & 6 & 8 & 10 & 12 & 14 & 16 & 18 & 20 & 22 & 24 \\
\hline 4 & 61,2 & & & & & & & & & \\
\hline 6 & 43,9 & 67,0 & & & & & & & & \\
\hline 8 & 34,7 & 52,7 & 73,0 & & & & & & & \\
\hline 10 & 29,0 & 43,9 & 60,8 & 79,2 & & & & & & \\
\hline 12 & & 37,9 & 52,3 & 68,2 & & & & & & \\
\hline 14 & & & 46,2 & 60,1 & 75,2 & & & & & \\
\hline 16 & & & 41,4 & 53,9 & 67,4 & 81,8 & & & & \\
\hline 18 & & & & 49,0 & 61,2 & 74,3 & 88,2 & & & \\
\hline 20 & & & & & 56,0 & 68,2 & 80,9 & 94,3 & & \\
\hline 22 & & & & & & 63,1 & 74,9 & 87,2 & 100,2 & \\
\hline 24 & & & & & & & 69,7 & 81,2 & 93,3 & 105,8 \\
\hline 26 & & & & & & & & 76,1 & 87,4 & 99,1 \\
\hline 28 & & & & & & & & & 82,2 & 93,3 \\
\hline 30 & & & & & & & & & & 88,2 \\
\hline
\end{tabular}

Табл. 6. Фітомаса кори стовбурів у абсолютно сухому стані, $\mathbf{T} \cdot \mathbf{r a}^{-1}$

\begin{tabular}{|c|c|c|c|c|c|c|c|c|c|c|}
\hline Діаметр & \multicolumn{10}{|c|}{ Висота, м } \\
\hline & 6 & 8 & 10 & 12 & 14 & 16 & 18 & 20 & 22 & 24 \\
\hline 4 & 2,3 & & & & & & & & & \\
\hline 6 & 2,1 & 3,8 & & & & & & & & \\
\hline 8 & 2,0 & 3,6 & 5,7 & & & & & & & \\
\hline 10 & 1,9 & 3,5 & 5,5 & 7,9 & & & & & & \\
\hline 12 & & 3,3 & 5,3 & 7,7 & & & & & & \\
\hline 14 & & & 5,1 & 7,5 & 10,2 & & & & & \\
\hline 16 & & & 5,0 & 7,3 & 10,0 & 13,1 & & & & \\
\hline 18 & & & & 7,1 & 9,8 & 12,9 & 16,4 & & & \\
\hline 20 & & & & & 9,6 & 12,6 & 16,0 & 19,9 & & \\
\hline 22 & & & & & & 12,4 & 15,8 & 19,6 & 23,8 & \\
\hline 24 & & & & & & & 15,5 & 19,3 & 23,4 & 28,0 \\
\hline 26 & & & & & & & & 19,0 & 23,1 & 27,6 \\
\hline 28 & & & & & & & & & 22,8 & 27,2 \\
\hline 30 & & & & & & & & & & 26,9 \\
\hline
\end{tabular}

Табл. 7. Фітомаса стовбурів у корі в абсолютно сухому стані, $\mathbf{T} \cdot \mathbf{r a}^{-1}$

\begin{tabular}{|c|c|c|c|c|c|c|c|c|c|c|}
\hline Діаметр, & \multicolumn{10}{|c|}{ Виссота, м } \\
\hline & 6 & 8 & 10 & 12 & 14 & 16 & 18 & 20 & 22 & 24 \\
\hline 4 & 63,5 & & & & & & & & & \\
\hline 6 & 46,0 & 70,8 & & & & & & & & \\
\hline 8 & 36,7 & 56,3 & 78,7 & & & & & & & \\
\hline 10 & 30,0 & 47,4 & 66,3 & 87,1 & & & & & & \\
\hline 12 & & 41,2 & 57,6 & 75,9 & & & & & & \\
\hline 14 & & & 51,3 & 67,6 & 85,4 & & & & & \\
\hline 16 & & & 46,4 & 61,2 & 77,4 & 94,9 & & & & \\
\hline 18 & & & & 56,1 & 71,0 & 87,2 & 104,6 & & & \\
\hline 20 & & & & & 65,6 & 80,8 & 96,9 & 114,2 & & \\
\hline 22 & & & & & & 75,5 & 90,7 & 106,8 & 124,0 & \\
\hline 24 & & & & & & & 85,2 & 100,5 & 116,7 & 133,8 \\
\hline 26 & & & & & & & & 95,1 & 110,5 & 126,7 \\
\hline 28 & & & & & & & & & 105,0 & 120,5 \\
\hline 30 & & & & & & & & & & 115,1 \\
\hline
\end{tabular}

Фітомаса стовбурової деревини, кори та стовбурів у корі зростає зі збільшенням середніх висот, та незначно зменшується зі збільшенням середнього діаметра.

У діапазоні значень середнього діаметра деревостану 8-20 см стовбурова деревина в абсолютно сухому стані в досліджуваної породи становить 90,3-80,0%. Зі збільшенням значень середньої висоти деревостану частка деревини стовбура зменшується із закономірним збільшенням частка кори у структурі фітомаси стовбурів. Відсутність нормативів оцінювання біотичної продуктивності модальних робінієвих деревостанів за компонентами надземної фітомаси не тільки для Степової зони, а й загалом для України, робить неможливим порівняння отриманих результатів. 
Висновки. Розраховано регресійні моделі залежності компонентів фітомаси стовбурів деревостанів робінії несправжньоакації від основних таксаційних ознак насадження та встановлено можливість адекватного їх використання для розроблення нормативно-довідкових таблиць. В основу нормативів фітомаси компонентів стовбурів покладено трифакторну модель, до складу якої входять середній діаметр стовбурів, середня висота та відносна повнота насаджень.

Розроблені нормативи оцінювання компонентів фітомаси стовбурів насаджень досліджуваної породи в абсолютно сухому стані дають змогу оцінювати їх біотичну продуктивність та слугувати основою для прогнозування реалізації ними екосистемних сервісів у Північному Степу України.

\section{Перелік використаних джерел}

Carl, C., Biber, P., Veste, M., Landgraf, D., \& Pretzsch, H. (2018) Key drivers of competition and growth partitioning among Robinia pseudoacacia L. trees. Forest Ecology and Management, 430, 86-93. https://doi.org/10.1016/i.foreco.2018.08.002

Lakyda, P. I. (2002). Fitomasa lisiv Ukrainy. Ternopil: Zbruch, 256 p. [In Ukrainian].

Lakyda, P. I., Vasylyshyn, R. D., Lashchenko, A. H., \& Terentiev, A. Yu. (2011). Normative assessment of the components of the abo- veground phytomass of trees of the main forest species of Ukraine. Kyiv: Ekoinform, 192 p. [In Ukrainian].

Lakyda, P. I., \& Blyshhik, I. V. (2010). Phytomass alders of Western Polissya of Ukraine. Korsun-Shevchenkivskij: FOP Majdachenko I.S., 237 p. [In Ukrainian].

Lakyda, P. I., \& Sytnyk, S. A. (2014). Peculiarities of forest inventory structure of black locust stands Steppe in Dnieper Northern of Ukraine. Lisivnyctvo i agrolisomelioracija. Forestry \& Forest Melioration, 125, 25-31. [In Ukrainian].

Lazzaro, L., Mazza, G., d'Errico, G., Fabiani, A., et al. (2018). How ecosystems change following invasion by Robinia pseudoacacia: Insights from soil chemical properties and soil microbial, nematode, microarthropod and plant communities. Science of the Total Environment, 622-623, 1509-1518. https://doi.org/10.1016/j.scitotenv.2017.10.017

Liang, H., Xue, Y., Li, Z., Wang, S., et al. (2018). Soil moisture decline following the plantation of Robinia pseudoacacia forests: Evidence from the Loess Plateau. Forest Ecology and Management, 412, 62-69. https://doi.org/10.1016/i.foreco.2018.01.041

Liu, D., Huang, Y., Sun, H., \& An, S. (2018). The restoration age of Robinia pseudoacacia plantation impacts soil microbial biomass and microbial community structure in the Loess Plateau. Catena, 165, 192-200. https://doi.org/10.1016/j.catena.2018.02.001

Yantsev, A. V. (2012). Selection of statistical criteria. Symferopol: Publishing House TNU, 136 p. [In Russian].

S. A. Sytnyk

Dnipro State Agrarian and Economic University, Dnipro, Ukraine

\section{MODELING OF THE TRUNK PHYTOMASS COMPONENTS OF BLACK LOCUST STANDS IN NORTHERN}

STEPPE OF UKRAINE

One of the first steps for expedient management of black locust stands is the evaluation of biotic production of aboveground phytomass. The purpose of the article is to develop the standards for the evaluation of the trunk components of the aboveground phytomass of black locust stands within Northern Steppe of Ukraine. In the presented work, the method of collecting and processing by prof. P.I. Lakyda are used for the receiving of results. The statistical processing, correlation analysis and the search of regression dependences of components of black locust trunk phytomass from stands biometric indices are made. The paper presents the results of mathematical modeling of the trunk phytomass components - trunk wood, trunk bark and trunk in the bark, as well as their dependence on the basic stand biometric characteristics (average height, average diameter, relative density). The study was conducted on 20 temporary trial plots in the forest of Dnipropetrovsk Region, which are in the jurisdiction of the State Agency of Forest Resources of Ukraine. A working data array has been formed that characterizes the components of the phytomass of the trunk, which is necessary for assessing the biotic production of artificial forest stands. Statistical and correlation analyzes of experimental data have been performed to define the nature of the distribution of the parameters studied and to ensure the adequacy of mathematical models. In the obtained mathematical models, feedback is observed among the components of the phytomass of the trunk with the average diameter of the stands. The relative density of the stands is statistically significant at introducing it into the equation simultaneously with the average diameter and average height of the stands. The conversion coefficient (the ratio of the phytomass of the trunk in the bark to the total stock of trunks in the bark) is calculated. Its value ranges from 0.37 to 1.12 . The fragments of normative tables for the evaluation of the components of the trunks phytomass of black locust artificial stands with a relative density of 0.9 are given. The resulting normative trunk phytomass provide an opportunity to assess ecological and energy potential and calculate the carbon deposit in artificial black locust stands of the studied region.

Keywords: steppe; stands; regression equations; Robinia pseudoacacia L.; normative tables. 